Reproduced from The Comprehensive and Progressive Agreement for Trans-Pacific Partnership: Implications for Southeast Asia, edited by Cassey Lee and Pritish Bhattacharya (Singapore: ISEAS - Yusof Ishak Institute, 2021). This version was obtained electronically direct from the publisher on condition that copyright is not infringed. No part of this publication may be reproduced without the prior permission of ISEAS Publishing. Individual chapters are available at <http://bookshop.iseas.edu.sg>.

\title{
The \\ Comprehensive and \\ Progressive Agreement \\ for Trans-Pacific \\ Partnership
}


The ISEAS - Yusof Ishak Institute (formerly Institute of Southeast Asian Studies) is an autonomous organization established in 1968. It is a regional centre dedicated to the study of socio-political, security, and economic trends and developments in Southeast Asia and its wider geostrategic and economic environment. The Institute's research programmes are grouped under Regional Economic Studies (RES), Regional Strategic and Political Studies (RSPS), and Regional Social and Cultural Studies (RSCS). The Institute is also home to the ASEAN Studies Centre (ASC), the Singapore APEC Study Centre, and the Temasek History Research Centre (THRC)

ISEAS Publishing, an established academic press, has issued more than 2,000 books and journals. It is the largest scholarly publisher of research about Southeast Asia from within the region. ISEAS Publishing works with many other academic and trade publishers and distributors to disseminate important research and analyses from and about Southeast Asia to the rest of the world. 


\section{The \\ Comprehensive and \\ Progressive Agreement for Trans-Pacific Partnership \\ Implications for Southeast Asia}

EDITED BY

CASSEY LEE - PRITISH BHATTACHARYA

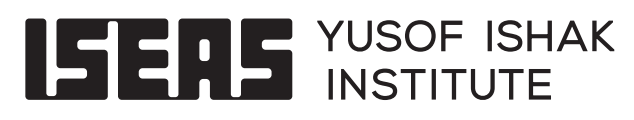


First published in Singapore in 2021 by

ISEAS Publishing

30 Heng Mui Keng Terrace

Singapore 119614

E-mail: publish@iseas.edu.sg

Website: <http:/ / bookshop.iseas.edu.sg>

All rights reserved. No part of this publication may be reproduced, stored in a retrieval system, or transmitted in any form or by any means, electronic, mechanical, photocopying, recording or otherwise, without the prior permission of the ISEAS - Yusof Ishak Institute.

(C) 2021 ISEAS - Yusof Ishak Institute, Singapore

The responsibility for facts and opinions in this publication rests exclusively with the authors and their interpretations do not necessarily reflect the views or the policy of the publisher or its supporters.

ISEAS Library Cataloguing-in-Publication Data

Name(s): Lee, Cassey, editor. I Bhattacharya, Pritish, editor.

Title: The Comprehensive and Progressive Agreement for Trans-Pacific

Partnership : implications for Southeast Asia / edited by Cassey Lee and

Pritish Bhattacharya.

Description: Singapore : ISEAS - Yusof Ishak Institute, 2021. I Includes bibliographical references and index.

Identifiers: ISBN 978-981-4818-87-2 (paperback) । ISBN 978-981-4818-88-9 (PDF)

Subjects: LCSH: Comprehensive and Progressive Agreement for Trans-Pacific Partnership-(2018 March 8). I Pacific Area cooperation. I Pacific AreaCommercial treaties. I Free trade-Economic aspects-Pacific Area.

Classification: LCC HF2570.7 C73

Cover illustration by Pritish Bhattacharya

Typeset by International Typesetters Pte Ltd

Printed in Singapore by Markono Print Media Pte Ltd 